\title{
LA EXPULSIÓN DE LOS MORISCOS DE ALCALÁ \\ LA REAL (1611)
}

\author{
Pedro Andrés Porras Arboledas \\ Universidad Complutense
}

\begin{abstract}
"Lo que importa es aprehender por qué motivos la operación de expulsión fue tan difícil de rematar. Veremos así cómo algunos moriscos, a diferencia de la gran masa, estaban en vías de asimilación, y que intentaron, al precio de esfuerzos desesperados, evitar el exilio y cómo la opinión pública, menos unida de lo que se piensa, se dividió acerca de la actitud a tomar respecto a ellos. [...] $\mathrm{He}$ aquí lo que, a pesar de la insignificancia de muchos episodios, hace a esta historia digna de ser aclarada."

«Particularmente hemos llamado la atención sobre esta especie de guerra que a partir de 1611 sostuvo el gobierno con los moriscos y sus defensores, guerra cuyos episodios habían excitado muy poco la curiosidad de los eruditos» (Lapeyre, op. cit., pp. 214 y 251).
\end{abstract}

Durante toda la Edad Media, la Península Ibérica se constituye en patria común de las tres grandes religiones monoteístas; salvo intervalos concretos, en el interior de los reinos cristianos y musulmanes de la Reconquista conviven los miembros de esas tres religiones: cristianos, musulmanes y judíos. Las circunstancias sólo comenzarán a cambiar a partir del siglo XIV, cuando la intransigencia religiosa recaiga sobre la minoría hebrea; sin embargo, sólo será tras el fin de la Reconquista cuando se empiece a cuestionar también la presencia de comunidades mudéjares en el seno del nuevo Estado castellano-aragonés; este Estado nace con ansias unitarias, lo que tendrá su correlato en el campo de lo religioso en la supresión de las comunidades no cristianas.

Dicha supresión se intentó, tanto en el caso de los hebreos como en el caso de los musulmanes, por dos vías: en primer lugar, mediante la conversión forzosa al Cristianismo y, luego, tras el fracaso de esta poco realista política ${ }^{1}$, mediante el recurso a la expulsión de todos estos

1 No todos los autores están de acuerdo en este tema; así, Lea hace una bonita apreciación sobre las frustradas posibilidades de aculturación de la minoría: «La compara- 
conjuntos inasimilables por la fuerza. Por lo que se refiere a los moriscos, en términos generales, adoptaron una política de resistencia a la asimilación que tuvo dos momentos de explosión bélica: los moriscos granadinos se sublevaron, primero a comienzos del siglo XVI, coincidiendo con los bautismos masivos, y en la segunda mitad del mismo (1563-1570), en ambos casos con idénticos resultados: la derrota militar y los consiguientes malos tratos a los vencidos.

Pero si la primera derrota se había saldado con el ajusticiamiento de los cabecillas, el esclavizamiento de algunas comunidades y la huida a África de algunas otras, la de 1570 tuvo consecuencias mucho más duraderas y de mayor alcance para todas las comunidades moriscas bajo soberanía castellano-aragonesa; en este caso, no sólo se impusieron castigos ejemplares para algunos de los levantados en armas, sino que, además, se tomó una medida general a todos los moriscos granadi-

ción entre el reducido contingente de exiliados y la numerosa población mora primitiva de los territorios ocupados durante la Reconquista, nos lleva a pensar en los muchos mudéjares que debieron abrazar el cristianismo y mezclarse con sus conquistadores hasta llegar a confundirse con ellos. La tolerancia medieval los había captado y, de haberse mantenido aquel clima, la asimilación habría sido total. No sólo se habrían evitado los infinitos sufrimientos que padecieron aquellas gentes sino que España, hasta cierto punto, habría escapado al empobrecimiento y la debilidad con que tan dolorosamente pagó por haberlos expulsados» (H. Ch. Lea, Los moriscos españoles. Su conversión y expulsión, Alicante, 1990, 361-362).

Por su parte, Márquez Villanueva se pregunta ¿cómo se llega a plantear una alternativa tan increíble como la de 1609? Tanto musulmanes como cristianos hispánicos están remisos a dejar a un lado sus prejuicios para reconocer, por encima de criterios religiosos, la integral españolidad del morisco, en cuanto punto de convergencia de tradiciones y circunstancias de absoluta peculiaridad y sin paralelo en Occidente. "Su única definición histórica, y hasta su única "patria", es la de un mudejarismo...». Frente a la tesis del fatídico enfrentamiento, hubo una época en que los españoles de ambas y hasta de las tres religiones se trataban familiarmente. Todo cambió con la introducción del Santo Oficio: es entonces cuando, abolida unilateral y violentamente la "solución mudéjar", surge el "problema morisco" (El problema morisco (desde otras laderas), Madrid, 1991, 4-7).

Epalza, por otro lado, entiende que, después de los trabajos de Márquez Villanueva y B. Vincent, está probado que el trágico final representado por la expulsión no era necesario (Los moriscos antes y después de la expulsión, Madrid, 1992,119). En este mismo sentido, entiendo que más que de expulsión tendríamos que hablar con propiedad de expatriación. Hoy en día la corriente predominante pretende reconstruir el mito andalusí de la convivencia de las tres culturas a fin de ofrecer un modelo válido para la coexistencia de las dos riberas mediterráneas en nuestro mundo actual (véanse los artículos incluidos en la obra colectiva Penser la Méditerrannée des deux rives. L'Héritage Andalou, Paris, 1995, en especial, las consideraciones de Thierry Fabre, "La pensée des deux rives», 5-7; Mikel de Epalza, «Le modèle andalou: une tolérance intolérable?», 117-122, y Jerónimo Páez, «La réappropiation d'un héritage commun», 150). 
nos: la expulsión interior. A partir del primero de noviembre de 1570 se decretó que todos los antiguos musulmanes del reino de Granada abandonasen sus propiedades y lugares de asentamiento para ser trasladados y repartidos por toda Castilla, a fin de hacer disminuir su potencial peligrosidad para la comunidad cristiana, harta de sobresaltos y obsesionada, como estaba, con el peligro turco.

Gracias a esta traumática medida -se calcula que un $30 \%$ de los moriscos expulsados fallecieron durante el trayecto o a resultas del mismo ${ }^{2}$-, la Andalucía Bética y Castilla la Nueva, además de Extremadura, se vieron obligadas a acoger a esta tropa de hambrientos y depauperados moriscos, quienes debieron iniciar una nueva vida en estos lugares de acogida. El recibimiento con que se encontraron varió mucho de unos lugares a otros; sin embargo, llama la atención que fuera precisamente en la Andalucía del Guadalquivir donde mejor acogida se les dispensó y donde, al parecer, mejor posición económica alcanzaron ${ }^{3}$. En concreto, a Alcalá la Real, lugar tan cercano y tan emparentado por vínculos de todo tipo con la ciudad de Granada, llegaron al poco de la expulsión 250 esclavos moriscos, que permanecieron allí muy bien considerados y amparados por los vecinos y municipio; no hay que olvidar que eran buena mano de obra y barata.

Concretamente, sabemos que tanto en 1573 y 1574 la ciudad mostró claramente su disconformidad con las medidas de expulsión a Castilla de esos moriscos, impidiendo su salida. A pesar de lo cual, en esta ocasión saldrían los 250 esclavos. En 1580, el Rey fue informado de la actitud de los alcalaínos en los siguientes términos:

Lo querían apedrear [al Corregidor de Alcalá] los vecinos, porque lo sintieron más que si les sacaran sus mismos hijos, tanto es el amor que tienen con ellos y el aborrecimiento con quien hace executar lo que se les man$d a^{4}$.

Aún en enero de 1584 la ciudad de Alcalá junto con Antequera, Loja y Guadix, además de los prelados de Granada y Guadix, solicitó

2 Domínguez Ortiz, A., y Vincent, B., Historia de los moriscos. Vida y tragedia de una minoría, Madrid, 1978, 52.

3 Según las Relaciones de Cabrera de Córdoba, la expulsión de 1610 se llevó a cabo de una manera muy rigurosa, afectando, al menos, en Sevilla y Córdoba a «personas muy ricas y con oficios muy honrados" (Caro Baroja, J., Los moriscos del Reino de Granada. Ensayo de Historia social, Madrid, 1976, 227).

4 Domínguez y Vincent, 68. 
expresamente que se retrasase de nuevo la expulsión a Castilla, a pesar de lo cual 97 moriscos fueron expulsados en esa ocasión ${ }^{5}$. Parece ser que estas medidas tuvieron algún efecto, ya que moriscos hubo en Alcalá hasta su expulsión definitiva en 1611. Sabemos, asimismo, que personas llegadas en 1585 aún permanecían en la ciudad en aquel año, como es el caso del mercader Melchor de Góngora, que alcanzaría ejecutoria de cristiano viejo y se casaría, gracias a su riqueza, con una cristiana vieja, si bien sería expelido como morisco en 1611. Se conserva en el Archivo Municipal de Alcalá la Real un padrón del año 1587, donde puede rastrearse la población morisca asentada en la ciudad, dedicada a labores de albañilería, trajinería o trasiego del vino, especialmente ${ }^{6}$.

No es difícil explicar la actitud de los alcalaínos en esta coyuntura: Alcalá la Real había sido durante el último siglo y medio de la Reconquista una plaza militar avanzada contra el reino de Granada; Alcalá se había constituido, pues, en un importante centro militar y de espionaje para los cristianos, pero, al mismo tiempo, se había convertido en un lugar privilegiado de recepción de personas que, en términos generales, podríamos denominar como renegados, es decir, musulmanes huidos desde el otro lado de la frontera, que por diversas causas -especialmente políticas - deciden instalarse en tierras castellanas y cristianizarse $^{7}$. Este conjunto de personas, ciertamente limitado en el número to-

5 Lapeyre, H., Geografía de la España morisca, Valencia, 1986, 156.

6 Juan Lovera, C., "Importancia de los moriscos gaçís en la fabricación del vino, según documentos del Archivo Municipal de Alcalá la Real», Homenaje a Antonio Domínguez Ortiz, Madrid, 1981, 263-267. Había suplicado el Concejo en enero de 1584 al Rey que no expulsara a la población morisca por no ser peligrosa, ser necesaria para la economía local y por no pertenecer la ciudad al reino de Granada. Uno de los encargados de mover las recomendaciones pertinentes en la Corte fue significativamente un regidor llamado Rodrigo de Góngora. A pesar de la expulsión, algunos quedaban aún en diciembre de 1585: según me comunica amablemente la anterior autora, las únicas personas que aparecen como expresamente moriscas en el padrón de 1587 son las siguientes: en la calle Utrilla, Isabel morisca; en el barrio de La Mota, calle del Preceptor, María de Castro morisca y en la calle Pedro de Valenzuela, Lorenzo de Mendoza, morisco; Bahondillo y Lorenzo de los Ríos morisco; en la calle Veracruz, Alonso del Aguila morisco; en la calle San Juan, Juan de Aranda gasí; asimismo, consta en la reunión de Cabildo municipal de 3 de diciembre de 1585 el también gasí Juan Izquierdo.

7 Sobre estos particulares puede verse mi trabajo «El Derecho de frontera durante la Baja Edad Media. La regulación de las relaciones fronterizas en tiempo de treguas y de guerra", Estudios dedicados a la memoria del profesor L. M. Díez de Salazar, Bilbao, 1992, I, 261-263. 
tal, acabaría emparentando con la población cristiana sin grandes problemas durante los siglos XIV y XV.

Los linajes aristocráticos alcalaínos no serían precisamente los más reacios a emparentar con estos antiguos muslimes ${ }^{8}$; en el caso de la cercana Jaén tenemos documentado el ejemplo del capitán García de Jaén, al parecer, caballero granadino establecido en Jaén, que desempeñó un importante papel en la vida fronteriza durante el reinado de los Reyes Católicos, y que dio lugar a un notable linaje: el de los Vélez de Mendoza, emparentados con los descendientes del obispo de Jaén, don Alonso Suárez de la Fuente del Sauce, que obtuvieron importantes concesiones en los repartimientos de la ciudad de Granada y sus alrededores una vez terminada la conquista 9 . Parece ser que en Andújar el mestizaje estaba muy extendido, si hemos de creer a un embajador marroquí que pasó por allá en 1690-1691: «De los moradores de Andújar asegura descienden en gran parte de los abencerrajes que, perseguidos por Muley Hacén, huyeron a tierra de cristianos y abrazaron su fe. De ellos desciende gran parte de la nobleza de dicha ciudad; pero mientras algunos de ellos reivindican con orgullo tal ascendencia, otros la repudian y se pretenden originarios de las montañas de Navarra" ${ }^{10}$. Sea esto cierto o no, es sabido que una parte de la antigua nobleza y Casa real nazaríes sobrevivieron cristianizadas en la España Moderna ${ }^{11}$.

Pues bien, esta permeabilidad de la sociedad alcalaína explicaría, en parte, esta actitud de protección a los moriscos, que como vamos a ver en seguida, se mantendría hasta los momentos finales de la expulsión definitiva, procurando salvar todo lo salvable, aprovechando todos los resquicios que los bandos de expatriación permitían. El documento que transcribimos e incluimos como apéndice principal es bien indicativo de dicha permeabilidad, ya que encontramos al menos 25 matrimonios mixtos sólo entre cristianos viejos y moriscas, siendo estas mo-

8 Esta misma permeabilidad se puede colegir de la tolerancia hallada por los gitanos en la ciudad alcalaína pocos años después de la expatriación de los moriscos; véanse los artículos de Carmen Juan ("Aportaciones documentales a la Historia de los gitanos en Andalucía (Los gitanos de Alcalá pusieron picas en Flandes)", Boletín del Instituto de Estudios Giennenses, CII (1980), 41-55) y Toro Ceballos, F. ("Salvoconductos para gitanos en el siglo XVI", Programa de la Feria de San Mateo, Alcalá la Real, 1994, 9-12) sobre dicha minoría.

9 Bonilla, A., y Toral, E., El tratado de paz de 1481 entre Castilla y Granada, Jaén, 1982, 48.

10 Lapeyre, 263.

11 Soria Mesa, E., «De la conquista a la asimilación. La integración de la aristocracia nazarí en la oligarquía granadina", Areas, XIV (1992), 49-64. 
riscas tanto de primera - hijas de padre y madre moriscos- como de segunda generación - hijas de padre cristiano viejo y de madre moriscas-. Por lo que se refiere a los matrimonios entre moriscos y cristianas viejas, a quienes no se les exceptuará de la expatriación, se permitirá a las mujeres seguir a sus maridos o abandonarlos. Además, entre los cristianos viejos enlazados en estos matrimonios hallamos desde mercaderes adinerados a pobres de solemnidad, pasando por agricultores y pequeños comerciantes, sin que la "repugnancia étnica» alcanzase a portugueses ni a vizcaínos ${ }^{12}$. A este respecto, Márquez Villanueva llama la atención sobre el hecho de que el Islam tuvo su talón de Aquiles en la codicia erótica despertada por la mora en la austera sociedad cristiana: la conversión ofrecía notables ventajas para el medro matrimonial, bien como requisito previo, sea como regularización de uniones clandestinas con cristianos; por ello se habían tomado medidas contra el mestizaje ya en las capitulaciones ${ }^{13}$.

Las medidas tomadas en orden a repartir a los moriscos granadinos por toda Castilla, al parecer, no alcanzaron los efectos apetecidos, planteándose en la Corte de Felipe III la necesidad de expulsar del reino a todos los moriscos, tanto a los súbditos castellanos como a los aragoneses. Tras una serie de vacilaciones, el monarca, influido por la Reina, acabó por decretar en 1609 el extrañamiento de todos los ciudadanos de origen morisco de sus reinos. Una vez finalizada la expulsión de valencianos, se produjo la de los andaluces, murcianos y de Hornachos, siendo dirigidas las operaciones por don Juan de Mendoza y Velasco, Marqués de San Germán; éste comenzó por escribir a justicias y corregidores que le enviasen padrones detallados de los cristianos nuevos de sus áreas, mediante los cuales pudo constatarse cómo el grueso de la población morisca se hallaba en los reinos de Jaén y Córdoba, siendo mucho menor la presencia en Sevilla ${ }^{14}$ y Granada -a

12 Archivo Histórico Provincial de Jaén, protocolo 4.870, pieza aparte, conservada dentro de un protocolo del escribano público alcalaíno Juan Rodríguez de Cebreros. Se trata de la información original con el oficio de remisión escrito de puño y letra del alcalde mayor, siendo el resto del escribano público Juan Rodríguez, si bien en dos ocasiones se aprecia una mano distinta. La numeración del documento permanece constante desde el principio hasta el folio 41, a partir del cual salta hasta el 54, que es el último de todos. En el apéndice documental sólo recogemos las piezas más importantes.

13 El problema morisco, 19 , nota 7.

14 Una explicación sobre la escasa presencia en Sevilla nos la ofrece el propio Marqués de San Germán, según el cual, allá cristianos viejos y nuevos se hallaban muy mezclados y, además, éstos pasaban desapercibidos por tener una lengua y unos vestidos similares a los de aquéllos (Lapeyre, 182). 
cuya circunscripción pertenecía Alcalá la Real ${ }^{15}$-. El bando lleva fecha del 9 de diciembre de 1609, pero no se difunde en Sevilla hasta el 10 de enero de 1610. A las localidades cordobesas tarda una semana en llegar; así los munícipes de Córdoba lo reciben los días 13 y 14 de enero, debiendo leerse públicamente el domingo 17, día de San Antón. En Jaén el bando se publicó a las 9 de la noche del día 17, tan pronto llegó a manos del Corregidor ${ }^{16}$, y en Murcia al día siguiente. Estas órdenes se ejecutarán de manera rigurosa.

El bando hacía referencia al fracaso en la asimilación y adoctrinamiento de la minoría, a los problemas de orden público creados por los moriscos y a la deslealtad hacia la Corona de éstos. Sólo se exceptuaban de la expulsión los esclavos moriscos. Se fija en treinta días el plazo de salida, con penas rigurosas para los que no saliesen o para los cristianos que los amparasen. Los bienes raíces se aplicaban a la Corona, en tanto que muebles y semovientes podían ser enajenados, cuyo producto debía ser invertido en mercancías autorizadas, pero no en metales, joyas ni letras de cambio, pudiendo sacar sólo el dinero necesario para los gastos del viaje. Se decreta la protección de los expulsados. A diferencia de lo ocurrido en Valencia, no se establece la excepción del $6 \%$ de las familias, los menores de cuatro años, los hijos de matrimonios mixtos menores de seis años y los que hubieran vivido entre cristianos sin contactos con las aljamas o que hubieran obtenido licencia para comulgar.

La orden de expulsión atañe a toda la población, sin más excepción que los cautivos; tanto los nobles como el alto clero ofrecen una tímida oposición, mientras que el pueblo se alegra con la misma y los moriscos la acogen con resignación ${ }^{17}$. Sin embargo, las reacciones de las oligarquías locales no fueron iguales en todas partes: en Jaén el cabildo pedía el día 24 de enero que se exceptuasen de la expatriación los moriscos o

15 Ibidem, 180-181.

16 Coronas Tejada, L., Jaén, siglo XVII. Biografía de una ciudad en la decadencia de España, Jaén, 1994, 175.

17 Doncel Aranda, J., Los moriscos en tierras de Córdoba, Córdoba, 1984, 350-353. Del mismo autor pueden verse «Los bienes inmuebles de los moriscos granadinos en el Reino de Jaén», Boletín de la Real Academia de Córdoba, CI (1980), 109-125; «Los esclavos en Jaén durante el último tercio del siglo XVI", Homenaje a Antonio Domínguez Ortiz, Madrid, 1981, 233-251; «Los bienes raíces de los moriscos andaluces en vísperas de la expulsión definitiva", Actas II Coloquios Historia de Andalucía. Andalucía Moderna, Córdoba, 1983, I, 151-168. En colaboración con Moreno Manzano, J., «La población morisca y su expulsión del Ducado de Sesa", Actas I Congreso de Historia de Andalucía. Andalucía Moderna, Córdoba, 1987, I, 33-53. 
moriscas casados con cristianos viejos y sus descendientes ${ }^{18}$; el consistorio granadino, al igual que el alcalaíno, se escudaría en la necesidad de mantener la presencia de algunos artesanos especializados o subalternos municipales, que consideraban insustituibles. Pero en Úbeda el caso es absolutamente sorprendente. Tanto el Concejo como el Cabildo adoptan su defensa: en general son gente pobre, que viven del trabajo del campo, o poseen alguna modesta tienda donde venden madera y semillas; jamás han conspirado contra el Rey, ni han sido acusados por el Santo Oficio; entre sus filas se cuentan algunas «beatas». Si es absolutamente necesario expulsarlos, que al menos sean encaminados hacia tierras cristianas (carta dirigida por la ciudad al Rey el 23 de enero de 1610) ${ }^{19}$.

A fines de enero de 1610, en Sevilla, el Marqués de San Germán contestaba a las dudas planteadas por el Corregidor de Baena en torno a las especiales situaciones de algunos moriscos:

a) Cristianos viejos casados con moriscas y sus hijos.

b) Moriscos casados con cristianas viejas y sus hijos.

c) Hijos legítimos nacidos de cristiano viejo y morisca o, a la inversa, que tienen probada su filiación y están autorizados para llevar armas.

d) Descendientes de moriscos, avecindados antes del levantamiento de 1568 , que han contraído matrimonio con cristianas y algunos de sus hijos han sido ordenados de "grado y corona".

e) Los que poseen ejecutorias de los tribunales de justicia declarándolos cristianos viejos.

f) Huérfanos menores de edad.

g) Moriscos ancianos, enfermos y tullidos.

h) Esclavos berberiscos manumitidos que han contraído matrimonio con moriscas.

La mayor parte de las consultas quedaron sin resolver hasta que el Rey dictó sus instrucciones en febrero, en las que eximía a los matrimonios mixtos integrados por cristiano viejo y morisca únicamente, así como a los hijos legítimamente nacidos, los descendientes de berberiscos y turcos convertidos a la fe cristiana, los moriscos granadinos que

18 Coronas, 176.

19 Lapeyre, 182 y nota 27. 
hubieran observado una buena conducta antes de la insurrección alpujarreña y los que hubiesen hecho voto de castidad. Todos los demás serían expelidos. También los moriscos se dirigirán a las autoridades locales para aclarar cuestiones relativas especialmente a la venta de sus haciendas 20.

A principios de febrero de 1610, liquidados los patrimonios, el bando ha sido ejecutado y los moriscos están prestos para salir hacia los puertos de embarque. El 27 de enero comienza el embarque en Sevilla y el sábado 6 de febrero empiezan a salir los de Córdoba capital. Sólo los moriscos de Priego consiguen escapar a la expulsión gracias a los buenos oficios del abad de Alcalá la Real, basándose en que en su mayoría habían repoblado la villa en 1486; el Rey concederá la dispensa cuando los moriscos ya se hallaban en el puerto de Málaga dispuestos a embarcar, causando un gran alborozo y regresando de inmediato ${ }^{21}$. Por otra parte, conocemos otros casos en que también se hicieron excepciones. En Quesada, adelantamiento de Cazorla, se quedaron 172 personas, 32 de las cuales esclavos, y algunos otros volvieron previa autorización del Corregidor. Por último, Pedro de Arriola habría concedido en la misma Málaga numerosas exenciones ${ }^{22}$.

Consumada la expulsión, se corre la noticia, exagerada, de que muchos están regresando, por lo que Felipe III dicta una cédula en 22 de marzo de 1611 ordenando expeler a todos los moriscos que quedaban en Castilla y a los que se habían vuelto y fingían vivir como buenos cristianos. Esta real cédula imponía medidas rigurosas: expulsión de los granadinos, incluso los que habían encargado pesquisas que demostrasen su conversión, por resultar sospechosas; los que habían obtenido de los jueces competentes sentencias a su favor podrían disponer de sus bienes raíces y serían enviados a países cristianos ${ }^{23}$. Exagerado o no, el estado de opinión entendía, en palabras de fray Marcos de Guadalajara, que «en las justicias y personas a cuyo cargo estava el Andaluzía, Reyno de Granada, y de otras partes, no avía tanta diligencia en expeler los que allí avían quedado, y castigar los que se avían buelto como

20 Aranda, op. cit., 360-362.

21 Ibidem, 364-371.

22 1611-9-5. Granada. F. de Irarrazábal comunica al Rey «El capitán Arriola que reside en Málaga a cuyo cargo estuvo la embarcaçión passada, pareçe que dio muchas permissiones en el embarcadero para que se bolbiesen muchos moriscos a sus cassas y asimismo ay notiçia de aver dexado muchas moriscas que ay» (Lapeyre, 189 y nota 66 ).

23 Ibidem, 216. 
convenía" 24; en el mismo sentido se expresaba el Conde de Salazar, más tarde (6 de septiembre de 1613), cuando escribió a Jaén quejándose de lo mal que se habían ejecutado los bandos de expulsión allí por "los muchos valedores que tenían", "y ha llegado a que los moriscos expelidos y que han estado en Tetuán se vuelven y los amparan y hallan testigos de que son cristianos viejos» 25 .

En el primer semestre de 1610 se habían expulsado 30.000 moriscos andaluces, pero desde septiembre de 1610 la expulsión no avanzaba, produciéndose algunos incidentes hasta 1614, en que finaliza el proceso. Las causas que impedían la expulsión eran jurídicas (los granadinos se escudaban en la protección eclesiástica, los mudéjares se ofuscaban en distinguirse de los cristianos nuevos o alegaban privilegios de los Reyes Católicos) y materiales (regresos clandestinos o irregulares desde Berbería con el concurso de marinos franceses e ingleses); con este doble tipo de medidas los moriscos pretendían oponerse a la acción de gobierno, quien hubo de tomar una serie de disposiciones. A fines de abril de 1611 se propone el envío de comisarios, tres para Andalucía: sólo se exceptuarían los moriscos viejos o impotentes. En septiembre se ordenó volver a los comisarios, pues se suponía que habían culminado su trabajo. Para fin de año sólo quedaban en España los que litigaban sobre su condición de moriscos ${ }^{26}$. Naturalmente, se había establecido un tribunal especial, en los primeros momentos del proceso, compuesto por diversos alcaldes y asesores sevillanos, nombrados por el Marqués de San Germán, cuyas funciones eran declarar quiénes tenían la categoría de cristianos viejos y quiénes no. Al término de aquél, se habían librado 716 ejecutorias favorables frente a 416 desestimadas 27.

Francisco de Irarrazábal había sido designado comisario para el reino de Granada. El Marqués de La Algaba, en cuyo señorío se había descubierto una bolsa de moriscos, se quejó al Rey en término inusualmente duros de que lo confuso de la normativa permitía que algunos delatores atacasen a personas reputadas como cristianos viejos ${ }^{28}$.

24 Caro Baroja, 231-232.

25 Coronas, $181-182$.

26 Lapeyre, 213-217.

27 Ibidem, 235.

28 1611-7-5. Ardales: «pero agora que V.M. manda que todos salgan, sin ningún reservo, es caso confusíssimo y ocasionado para grandes desservicios de Nro. Sr. porque las passiones y enemistades de algunos se estienden a delatar de algunos que an estado en posesión de cristianos viejos.... (Idem, 219-220 y nota 27). 
La labor de Tadeo de Benavides en el reino de Jaén no fue muy fructífera, pues, a pesar de la orden real de proceder de plano a la expul: ión, sólo pudo sacar a 270 personas que se embarcaron en Málaga a principios de noviembre de 1611. En Granada, Irarrazábal demostró gran actividad, chocando con las justicias locales -al igual que vamos a ver que ocurrió en Alcalá la Real-, que le acusaban de proceder sin ton ni son contra personas honorables (1611-7-15. La ciudad de Granada denuncia al Rey «y los onbres onrrados con gran temor destar sujetos que cualquier enemigo la diga a boca que cualquier dellos es morisco"). Hasta el propio presidente de la Audiencia parece que ayudó a los moriscos: alrededor de 100, entre canalizadores, tintoreros y empleados del registro de la propiedad, se habían visto favorecidos. Por su parte, el comisario se quejaba de que los ricos obtenían con facilidad sus ejecutorias; de hecho, sólo se constatan 41 favorables frente a ocho desfavorables. Gracias a su tenacidad, Irarrazábal obtuvo resultados notables: el 24 de julio embarcó en Almuñécar 95 personas y en septiembre salieron de Málaga con destino a Marsella otras 800, además de 270 enviadas por Benavides; sin embargo, según la costumbre establecida, de hecho todos iban para Berbería. No obstante, en los dos años siguientes se continuó con la expatriación de los exiliados que habían vuelto, así como la de muchos otros que no habían salido antes 29 .

Si el Marqués de San Germán había sido encargado de la expulsión en toda Andalucía, el delegado para el reino de Granada en 1611 sería don Francisco de Irarrazábal y Andía, el cual, a su vez, nombró comisarios subdelegados que se repartieron por todos los confines del reino, cada uno con jurisdicción en una ciudad o villa determinadas, además de sobre sus aldeas. A Alcalá la Real resultó destinado el alférez Marcos Pérez de Prado, joven de veinticuatro años, militar sin experiencia en asuntos administrativos, el cual actuaba, según las denuncias que contra él se presentaron, sin consejo de asesores ni letrados.

El alférez llegó a Alcalá a mediados del mes de junio de 1611 -su actuación más antigua la tenemos documentada el 18 de junio-, asentando su audiencia en la ciudad, para lo cual recabó los servicios del procurador alcalaíno Pedro de Oñate como fiscal y del escribano público Diego de Velasco como escribano de la comisión. Ambos personajes, como buenos conocedores de sus convecinos, tendrán gran responsabilidad en la actitud excesivamente inquisitiva del comisario

29 Idem, 221-222 y nota 38. 
Pérez. Asimismo, éste contó con los servicios de varios alguaciles y cierto número de arcabuceros, de identidades desconocidas. Los salarios diarios de todos estos ejecutores de las medidas de expul alcanzaban la no desdeñable suma de $2.400 \mathrm{mrs}$. (1.000 el comisário, 600 el alguacil, 500 el escribano y 300 el fiscal). Además, el escribano, hombre ciertamente rapaz, cobraba tres reales por cada registro de morisco y entre tres y 12 reales por cada petición a la que daba curso.

Durante el primer mes de sus actuaciones en la ciudad se levantó un gran clamor en contra del mismo comisario y sus oficiales a causa de los abusos que se decía estaban cometiendo contra cristianos y moriscos. El escándalo y las murmuraciones llegaron a ser tales que la justicia de la ciudad se vio obligada a tomar cartas en el asunto, y, tras ella, el propio municipio. Así, el 18 de julio el alcalde mayor, el doctor Basilio Alonso Suárez, redactó un oficio dirigido al Rey dándole cuenta de todos los abusos cometidos por el joven comisario; además, para un mejor conocimiento de los hechos, el alcalde tomó declaración a siete testigos, escogidos entre las personas más relevantes de la ciudad, los cuales corroboraron punto por punto las acusaciones del alcalde, presentando, incluso, un panorama más sórdido de la situación creada en Alcalá en el último mes. Concretamente, depusieron dos presbíteros, Juan de Frías Vázquez y Alonso de Rojas, dos personas de calidad y linaje, don Juan del Castillo Hinojosa y don Fernando Cabrera y Aranda, y tres regidores del municipio, Pedro Vázquez Mesía, don Rodrigo de Mendoza y Miguel de Utrilla.

Las quejas eran muy variadas, si bien las podemos resumir del siguiente modo:

- Presumía de tener comisión ilimitada en el tiempo, con lo que se podía perpetuar en la ciudad llevando a cabo actuaciones no relacionadas con su comisión y causando ingentes gastos a la población, a tenor de los salarios y costas que percibían el comisario y sus oficiales.

- Se extralimitaba respecto a las atribuciones que se le habían encomendado en su comisión, actuando contra aquéllos que tenían mezcla de sangre por línea paterna y contra los cristianos viejos casados con moriscas que estaban exceptuados de las medidas de expulsión.

- Efectuaba repartimientos de costas y salarios a estos exceptuados, resultándole, además, un beneficio neto, ya que recaudaba más de lo necesario; no daba cartas de pago más que a regañadientes, cometía 
todo tipo de arbitrariedades en la cobranza y el escribano se apropiaba parte de la recaudación. Continuaba actuando de esta manera a pesar de que un afectado se había quejado al comisario Irarrazábal y éste le había dado la razón.

- Procedía contra los testigos de informaciones realizadas anteriormente sobre la condición de moriscos de diversas personas, persiguiendo como encubridores a personas tan significadas en la ciudad como el licenciado Francisco de Gamboa, letrado del ayuntamiento, a Francisco de Herrera y Valenzuela, regidor y depositario general de la ciudad, y a Luis de Narváez Luján y su familia, todos los cuales habían declarado en proceso seguido en Granada contra Andrés de Mendoza y su mujer.

- Amenazaba a los testigos con excomunión reservada al Papa; los ponía en prisión tras una información sumaria; les confiscaba todos sus bienes; mandaba encarcelarlos sin acusación, como había ocurrido con Juan de Retarta; realizaba diligencias fuera de su jurisdicción, concretamente en Priego, lugar de concentración de buen número de moriscos; realizaba los interrogatorios bajo amenazas y falseaba las actas de las declaraciones de los testigos.

- Admitía informaciones contra cristianos viejos; informaciones sumarias contra linajes honrados, con buen número de eclesiásticos en sus filas, remontándose ciento treinta años atrás, medidas que afectaban especialmente a los cristianos viejos casados con moriscas, resultando de todo ello venganzas familiares e infamia para todos los implicados. Las actuaciones habían sido especialmente rigurosas en el castillo de Locubín, donde los caballeros y otros vecinos se habían opuesto al comisario diciendo que lo que hacía era un disparate.

- Se le achacaba, en suma, que perdía el tiempo infamando a los linajes ricos e importantes - de los que podía sacar buenas cantidades de dinero- y no cumpliendo con su principal cometido: proceder a la expulsión de los moriscos pobres.

Esto último no era totalmente cierto, ya que, si hemos de creer las declaraciones de estos siete personajes, al poco de llegar a la ciudad, el alférez había hecho registrar, en cumplimiento del bando del Marqués de San Germán, a toda la población morisca, so pena de muerte y de pérdida de todos sus bienes; el rigor con que se hizo fue tal que se incluyó a todos los que tenían sentencias firmes o a los que tenían sus procesos pendientes ante los alcaldes de Sevilla; además, fue obligatorio que todos se registrasen personalmente, con lo que se produjo un 
gran trasiego nocturno, en especial de mujeres, a la posada del comisario para evitar ser reconocidas. De poco les valdrían esas precauciones, pues a los pocos días el comisario dictó, con gran aparato - con cajas y atabales y sus oficiales montados a caballo-, un nuevo bando, ordenando que al día siguiente todos los que se habían registrado compareciesen en el Corral de las Comedias, situado junto al patio de la Veracruz, a fin de pasarles lista y nombrarles comisarios que los llevasen a los puertos donde iban a ser embarcados.

Aunque con esto no se pretendía expulsar también a estas cristianas nuevas casadas con cristianos viejos y a sus hijos, lo cierto es que el hecho de reunirlas públicamente con toda su familia dio lugar a gran escándalo e infamia, ya que muchas moriscas de éstas no eran tenidas por tales en la ciudad, y era mucho el gentío que se había reunido para contemplar el alistamiento. Estos hechos infamantes, sin ninguna utilidad para el objeto de la comisión, fueron muy comentados por los alcalaínos, junto con las actuaciones del alférez por las que persiguió a personas importantes de la oligarquía local: así, fueron encarcelados, gravados con fuertes derramas y confiscados los bienes del licenciado Francisco de Gamboa, letrado de la ciudad, y de Francisco de Herrera y Valenzuela, regidor y depositario general. Las presiones también alcanzaron a Luis de Narváez Luján; en todos los casos se les acusaba de encubrir con sus testimonios a moriscos que querían hacerse pasar por cristianos viejos.

Sin embargo, el caso que más repercusión alcanzó fue el del mercader Melchor de Góngora, asentado en Alcalá en 1585, que había alcanzado ejecutoria de cristiano viejo de los alcaldes de Sevilla y se había casado con una cristiana vieja. Considerado por el comisario como morisco, fue expelido a Motril para ser embarcado rumbo a Africa, aunque al día siguiente fue devuelto a Alcalá y desde ahí enviado a Granada para someter el conocimiento del asunto al comisario Irarrazábal; su mujer e hijos fueron expulsados de su casa y tienda, delante de las cuales colocó arcabuceros de guardia, sin darles tiempo a coger lo necesario para comer o dormir. Todos sus bienes fueron secuestrados. Pero lo que más conmovió a sus vecinos fue saber que había sido condenado sin darle audiencia ni permitirle que se defendiera. Y es que el comisario Pérez de Prado tendía a cebarse con los más ricos de los que podía sacar mayor provecho económico.

Terminadas estas primeras actuaciones del alcalde mayor sobre los excesos del comisario Pérez, el concejo también tomó sus medidas, di- 
putando para ello a dos de sus regidores, don Diego Cabrera y Pedro de Barrionuevo Aragonés; éstos dos comparecieron el día 19 de julio ante el alcalde mayor y le pidieron les diese traslado de la información referida, lo que se efectuó el día siguiente. Entre tanto, el comisario ya había tenido conocimiento de la información del alcalde mayor contra su persona, por lo que rápidamente, para evitar que aquél se informase sobre los motivos que tenía para haber metido a varias personas en la cárcel pública -se sospechaba que lo había hecho arbitrariamente-, ordenó sacarlos a todos ellos del calabozo para expedirlos de inmediato para Granada. Nuevamente, el alcalde mayor mandó tomar declaración de tres testigos sobre esta premura en desalojar los calabozos y el modo en que se acababa de efectuar. Declararon el teniente del alcaide de la cárcel, un vecino que se hallaba cerca del lugar de los hechos y un adolescente preso en la misma cárcel.

Ante la imposibilidad de entrevistarse con los presos del comisario, el doctor Basilio Alonso, alcalde mayor, decidió presionar al escribano Diego de Velasco a fin de que le facilitase un testimonio notarial sobre los bienes secuestrados por el comisario, los repartimientos que había derramado, las personas que había encarcelado y las causas de su prisión. Por dos veces, los días 19 y 20 de julio, el mencionado alcalde requirió al escribano Velasco para que le entregase lo que le pedía, y por dos veces recibió por respuesta la imposibilidad de hacerlo, ya que el comisario había arrebatado a su escribano el testimonio que éste había sacado de sus papeles originales y le impedía verlos de nuevo. No le quedó, pues, al alcalde mayor más remedio que dirigir su requerimiento al escurridizo comisario Pérez, el cual al día siguiente ( 22 de julio) lo único que mandó fue una copia con el texto de su comisión. Al mismo tiempo, para evitar el mal uso de los bienes secuestrados por el comisario, ordenó el alcalde mayor dar orden a los depositarios de estos bienes, el regidor Miguel de Utrilla, Pedro Vázquez Mesía, Juan de Ortega y el regidor Pedro de Barrionuevo Aragoneses, de que no librasen ninguna cantidad sobre estos bienes en depósito al comisario ni a sus oficiales, cosa que aceptaron los cuatro de buen grado.

Finalmente, los días 22 y 24 de julio el alcalde mayor tomó declaración a quince testigos sobre los repartimientos abusivos derramados por el comisario Pérez para sufragar sus salarios entre los cristianos viejos casados con moriscas; como resultado de esta investigación se 
supo que se habían recaudado más de 50.000 mrs., siendo los repartos conocidos los siguientes:

Doña Juana de León (o de La O) 20 ducados

Lcdo. Francisco de Gamboa 20 ducados

Juan Ruiz Doncel mercader 10 ducados

Pedro Cecilio mercader 10 ducados

Lorenzo Muñoz 5 ó 10 ducados

Alonso Hernández 2 ducados

Salvador de Raya 1 ó 2 ducados

Juan de Flores labrador 2 ó 6 ducados

Sebastián Sánchez 2 ducados

Juan Hernández cocinero 2 ó 6 ducados

Pedro Hernández de Castilla 2 ducados

Miguel García casero 2 ducados

Alonso Fernández de Vioso 1 ducado

Alonso de Almodóvar 1 ducado (rebajado a 8 reales)

Isabel Gutiérrez 1 ducado

Martín Ruiz Suárez 1 ducado

Juan Ruiz Chabarrías 1 ducado

Gaspar Hernández Portugués 1 ducado

Garrida 1 ducado

Baltasar Ruiz 1 ducado

Miguel Sánchez de Iváñez 30 reales

Martín Iváñez 30 reales

Bastián (cantidad indeterminada)

Diego de Contreras (cantidad indeterminada)

Bernabé de Montilla (cantidad indeterminada)

El suegro de Bernabé de Montilla (cantidad indeterminada)

Por desgracia, el documento está incompleto y no nos facilita otra información más allá del 24 de julio de 1611 , aunque no es ficción conjeturar una situación de enfrentamientos entre las autoridades locales alcalaínas y el joven e inexperto comisario de la expulsión.

Como colofón final, entiendo que habría que hacer una doble consideración según el punto de vista desde el que consideremos los hechos relatados. Así, si nos ponemos en el lugar del alférez Pérez de Prado, hombre sin duda poco práctico en estas lides administrativas, es 
evidente que actuó con un rigor desproporcionado, propio de la rudeza de ciertos hábitos castrenses; sin embargo, cabe cuestionarse sobre si realmente sobrepasó el ámbito de su mandato. Sin duda, su actuación fue poco delicada, en la medida en que lesionó la fama y el honor de muchas personas, sobre todo de aquéllos que con tanto cuidado habían intentado evitar que se supiese que sus mujeres eran moriscas y de aquéllos que habían defendido a los moriscos finalmente expulsados; en esta misma opinión ya hemos visto que concidían tanto el Marqués de La Algaba como el Concejo de Granada, respecto de sus correspondientes comisarios. No obstante, fundamentalmente, debió de ceñirse al contenido de la comisión.

Su gran error, y éste sería el punto de vista de los airados alcalaínos, consistió en tomarse demasiado en serio su cometido: no se contentó simplemente con registrar y enviar a embarcar a todos los moriscos claramente comprendidos en los bandos de expulsión, sino que además intentó innovar en estos temas, olvidando la sociedad, tan permeable étnicamente, sobre la que estaba operando. Intentó enmendar la plana a los alcaldes del Marqués de San Germán, volviendo sobre los casos que ellos ya habían sentenciado respecto a la condición de cristianos viejos de muchos moriscos; intentó reabrir, sin tener derecho alguno ni jurisdicción, los casos seguidos años antes ante la Chancillería de Granada sobre los mismos temas y se entrometió a determinar él personalmente quiénes eran cristianos viejos y quiénes no. En su prepotencia llegó a presumir que los casados con moriscas eran también moriscos, debiendo éstos romper dicha presunción, abriendo informaciones que, en algunos casos, se remontaban a los años finales de la existencia del reino nazarí de Granada. En fin, atentaba contra la paz social existente en Alcalá la Real por aquellos años, en la que sólo algunos pocos estaban interesados en remover de sus sepulturas a sus antepasados musulmanes antiguos y cercanos. 


\section{APÉNDICE DOCUMENTAL}

1611, julio 18. Alcalá la Real

El Doctor Basilio Alonso Suárez, alcalde mayor de la ciudad de Alcalá la Real, comunica al Rey los excesos cometidos por el alférez Marcos Pérez de Prado, comisario delegado para la expulsión de los moriscos de esa ciudad, por don Francisco de Irarrazábal y Andía, juez comisario para dicha expulsión en el reino de Granada, durante el desempeño de esa comisión en el último mes; oficio de remisión de la información sobre dicho tema, que se incluye a continuación.

Señor:

El comissario a quien Vuestra Magestad cometió la expulsión de los moriscos del Reino de Granada embió por comissario a esta Ciudad para este efecto a Marcos Pérez de Prado, moço según su aspecto de veinte años; exercita la comissión con fiscal, alguacil y escribano, con repartimiento en cada un día de dos mil y quatrocientos maravedís entre todos, como parece de la información que con ésta embío; excede de la comissión, porque donde va hacienda, honor y quietud de tantos, no conprehendiendo el vando los que tienen mezcla por línea paterna ni las casadas con cristianos viejos indistintamente a compelido a todos que se anoten, con perpetua infamia suya, de sus maridos, descendientes y deudos, y les ha hecho repartimientos de costas y salarios, y procede criminalmente con testigos, so color que en otras informaciones dijeron contra lo que él pretende aberiguar, y secresta todos los bienes muebles y raíces, quitándoles con esto la defensa.

Y lo peor es que contra cristianos viejos admite informaciones y oye a quien le habla en secreto, y examina los testigos que le citan con aminaças y rigor, con lo qual muchos padecen sin culpa y esta Ciudad está inquieta, porque con esto no ay honra segura. La causa es ser tan moço y sin esperiencia el dicho Marcos Pérez, cobra de las partes los salarios tener tantos oficiales y asentada audiencia tan de propósito y fuera de los salarios ser sin comparación mayor el probecho de que se entende saca él y tanto oficiales de secreto de las dichas informaciones que haze, en lo qual consume el tiempo, y aunque a un mes que está en esta ciudad, hasta agora sólo a expelido un hombre estando declarado por cristiano viexo, y lo sacó públicamente con alguacil y arcabuceros, y al día lo bolvió.

Doy qüenta para que Vuestra Magestad mande poner el remedio que conbenga. Dios guarde la real persona de Vuestra Magestad. De Alcalá la Real, a 18 de julio de 1611. Doctor Basilio Alonso Suárez. 
Apertura de información por dicho alcalde mayor sobre los excesos cometidos por el mencionado comisario y deposiciones de siete testigos.

En la Ciudad de Alcalá la Real, en diez y ocho días del mes de jullio de myll y seiscientos y honce años, el doctor Basilio Alonso Suárez, alcalde mayor desta Ciudad, dixo que a su noticia es venido los excessos que se hacen en esta Ciudad por el comisario Marcos Pérez de Prado, nombrado para la expulsión de los moriscos por don Francisco de Yrarraçával y Andía, a quien se cometió la dicha expulsión del Reyno de Granada, procediendo contra cristianos biexos por estar casados por cristianas nuevas y otras cosas de esta calidad, llevando de salario mill maravedíes en cada un día y un alguacil seiscientos y escrivano quinientos y fiscal trecientos, con que en poco más de veinte días an llevado por repartimientos más de quinientos ducados, y para que se entienda y más sea informado, mandó hacer la ynformación siguiente. Doctor Basilio Alonso Suárez. Juan Rodríguez, escrivano.

[1] En la ciudad de Alcalá la Real, en dicho día diez y ocho de jullio del dicho año, el dicho alcalde mayor para la averiguación de lo contenido en la dicha caveza del processo, recivió juramento en forma de derecho de Pedro Bázquez Mesía, regidor desta Ciudad y vezino della, so cargo del qual, preguntado y por el dicho pedimiento, dijo que este testigo a oydo decir públicamente que el dicho Marcos Pérez, comisario sobre la expulsión de los moriscos, a hecho repartimientos de salarios a cristianos biejos que están casados con cristianas nuevas, como son Juan Ruiz Doncel y Pedro de Cicilio, mercaderes.

Que a oydo decir públicamente les repartió diez o doce ducados a cada uno, y porque se defendían para no los pagar les prendía, particularmente al dicho Juan Ruiz Doncel.

Y ansy mismo, a oydo decir que a Alonso Gutiérrez, que ansy mismo es tenido por cristiano biejo, por estar casado con María de Falcón, cristiana nueva, le repartió otros dos; y ansí mismo a oydo decir le repartió y llevó otros dos ducados a un yerno del dicho Juan Ruiz Doncel; y ansí mismo a un Juan de Flores que le avían repartido otros dos ducados, y que éste se fue a quejar a don Francisco de Yrarraçával, comisario que reside en la Ciudad de Granada, y que avía mandado bolvérselos y que no llebase a los hijos de cristianos biejos ni a ellos salarios ningunos.

Y en este tiempo andavan cobrando los dichos salarios un alguacil, que tienen nombrado para la dicha comisión, y no por la dicha orden cessó ni dejó de hacer la cobrança, y no a entendido ni sabido este testigo que ayan vuelto ninguna cosa de [lo] cobrado.

Y ansy mismo, a entendido este testigo que Sebastián Sánchez, cristiano biejo, le llevaron otros dos ducados por repartimiento por estar casado con cristiana nueva. 
Y ansí mismo a oído decir que a llevado y repartido salarios a otros muchos cristianos biejos por la misma cusa, que no se acuerda de sus nombres.

$\mathrm{Y}$ ansí mismo sabe este testigo que aviendo fecho publicar en esta Ciudad el dicho comisario el vando de Su Magestad, para que dentro de cierto término ende contenido todas las personas a quien comprendía el dicho bando se registrasen, so las penas contenidas en dicho bando, y cumpliendo con el dicho bando save este testigo se registraron todos los moriscos que estavan en esta Ciudad, ansí los que tenían sus caussas pendientes como los que tenían sentencias dadas en su favor por los alcaldes de la Ciudad de Syvilla, auditores y acesores del Marqués de San Jermán, a quien se cometió la dicha expulsión.

Y entendió este testigo que aviendo ydo algunas personas con poder y con petición a registrarse aunque tenían la dicha sentencia a su favor, les decía el dicho comisario y el escrivano de la comisión era necesario pareciesen personalmente a hacer el dicho registro, y así yban de noche muchas mugeres a casa del dicho comisario a se registrar, de que vino grande nota y murmuración.

Después de lo qual hizo publicar otro bando por todas las calles desta Ciudad con cajas y atabales, yendo el escrivano y el fiscal y dos alguaciles, por el qual mandó que todas las personas, honbres y mugeres, muchachos y niños, que les tocase la dicha expulsión, se juntasen otro día siguiente en el Corral de las Comedias para les alistar y nombrar comisarios que les llevasen, y en cumplimiento del dicho bando el dicho comisario hiço que pareciesen y saliesen a el dicho Corral munchas cristianas nuevas casadas con cristianos biejos y sus hijos, y se juntaron y les hiço pasar lista, de que vino muy grande escándalo en esta Ciudad, nota y murmuración, por averse juntado a ver lo susodicho muncho número de jente que estavan presentes, de que resultó afrenta a muchos cristianos biejos y sus hijos, porque no se tenía noticia de que sus mugeres fuesen tales cristianas nuevas, y a ellas se les siguió la misma afrenta por averlas sacado a una tan grande publicidad.

Y de aver fecho la dicha lista no a resultado exspeler a ninguna persona, sino echar como echó el dicho un repartimiento de salarios a los susodichos.

Y no solamente quiso exspeler a un Melchor de Góngora mercader prendiéndolo para ello y lo puso en la cárcel desta Ciudad y le secrestó todos sus bienes muebles y raíces, echando de su casa, a la calle a la muger del dicho Melchor de Góngora, que es cristiana vieja, con sus hijos, y cerrando las puertas, y puso cuatro arcavuceros de guardia. Y al dicho Melchor de Góngora le hiço sacar de la dicha prisión para lo llevar a Motril a envarcar con mucha jente de guardia y un alguacil que lo llevava, y luego, otro día lo bolvieron a esta Ciudad, y este mes vio este testigo el dicho alguacil y dos arcavuceros que volvieron y el mismo día con el mismo acompañamiento lo enbió a la dicha Ciudad de Granada.

Y ansy mismo save que el dicho Marcos Pérez de Prado gana salario y un alguacil, escrivano y fiscal que tiene, los cuales a oydo decir son los contenidos 
en la caveça del processo, de los quales se va aciendo pagado de los repartimientos que a fecho a las partes y sigún el tiempo que a que está aquí, que será un mes, poco más o menos, entiende a cobrado mucho más de lo que montan los salarios; y a oydo decir a los oficiales que no tiene tiempo limitado en su comisión y que se a de estar en esta Ciudad muchos meses.

Y para ello y entender en su comisión procede contra testigos de ynformaciones que de mucho tiempo atrás se hicieron ante las justicias ordinarias desta Ciudad y de otras partes, y so color de que dice que dijeron sus dichos en contra de lo que él averigua, procede contra ellos por testigos falsos y tiene tres personas por ello pressos y otros ausentes y atemoriçados y oy está haciendo dilijencias en la dicha razón en la Ciudad de Priego con dos escrivanos y alguacil, siendo lugar donde ay otro comisario, y en esto se entretiene dejando de hacer el negocio principal de la expulsión, que es a lo que bino, y conviene muncho a servicio de Dios y de Su Magestad que esto se remedie porque no se hace el yntento de su Magestad, que es expeler los moriscos, sino afrentar a personas honradas y que no lo son, y llevarles sus haciendas, y que sabe que con muchas estorsiones el dicho Marcos Pérez de Prado y su escrivano hacen que digan sus dichos los testigos, y no diciendo lo que quieren les dicen que ay excomunión reservada para el Papa, y que porque no dicen lo que les preguntan, dizen los susodichos que son moriscos y que an de dar ynformación de quién son sus padres, y que esto pasó con Juana de Contreras, tendera e vezina desta Ciudad, examinándola por tal testigo; y save que tomando su declaración al Licenciado Ganvoa, abogado desta Ciudad, el dicho juez y escrivano le apretaron tanto que lo obligaron que les dijese que aquella no era confesión, sino vejamen o tormento que le davan; y esto lo savía por haver oydo decir públicamente en esta Ciudad, y esto es lo que save por el juramento que tiene fecho, y lo firmó de su nombre, y que es de más de treinta años. Doctor Basilio Alonso Suárez. Pedro Bázquez Messía. Juan Rodríguez escrivano.

[2] En la dicha Ciudad de Alcalá la Real, en el dicho día, para la dicha ynformación el dicho alcalde mayor recivió juramento en forma de derecho de Juan de Frías Vázquez presbítero, vezino desta Ciudad, so cargo del qual preguntado por el dicho auto y caveça de ynformación, dixo de lo que save e pasare que el dicho Marcos Pérez comisario, que está en esta Ciudad entendiendo en la expulsión de los moriscos, le parece a este testigo que sigún los bandos que a hecho publicar a ecedido y ecede de su comisión, porque a fecho repartimientos de sus salarios suyos y del escrivano y alguacil y fiscal que tiene para la dicha comisión, que sigún el tiempo que a que está en esta Ciudad a sido muncho más la cantidad de los dichos repartimientos que los dichos salarios, cobrándolos de munchas personas cristianos viejos, por decir estar casados con moriscas, a los quales conforme a los bandos publicados no les comprehende ni habla con ellos. 
Y pasado el término que por el primero bando que publicó para que los moriscos se registrasen, hizo publicar otro con tambores y escrivano y fiscal y dos alguaciles a cavallo por toda esta Ciudad para que todos los hombres, mugeres, muchachos y niños otro día siguiente saliesen a pasar lista e se juntasen en el Corral de las Comedias para nombrar los alguaciles e comisarios que saliesen con ellos, y en cunplimiento del dicho bando salieron mugeres cristianas nuevas casadas con cristianos viejos y sus hijos, porque a ello fueron conpelidas, y les hiço pasar lista en el dicho Corral, estando presentes mucho número de jente que ocurrió y se juntó para ver lo susodicho, de lo qual uvo muy grande escándalo y murmuración en esta Ciudad, particularmente de clérigos e religiosos, porque parece muy mal por resultar dello ynfamia de los dichos cristianos biejos y de sus hijos y de las mugeres, por la grande publicidad que avía, y que munchas dellas no eran tenidas por moriscas.

Y ansy mismo el dicho Marcos Pérez excede en la dicha comisión procediendo contra las mugeres de estos dichos cristianos biejos y otras munchas personas no comprenhendidas en el bando de Su Magestad, y contra testigos que an dicho sus dichos antes de la publicación de los dichos bandos sobre la dicha expulsión, tratando de lo susodicho, por ocuparse muncho tiempo por no tener comisión limitada, dejando de hacer la dicha expulsión de las personas a quien les comprehende por ser pobres, y sólo endereçan con las personas ricas y que tienen dineros, y que el bando de Su Magestad no les comprehende. Todo lo qual le parece a este testigo y otros munchos ecessos que a hecho y hace proceden de ser el dicho Marcos Pérez honbre muy moço de a veinte e quatro años, a lo que este testigo le parece y en el sitio de soldado y sin exsperiencia de negocios. Todo lo qual conviene que Su Magestad lo remedie por ser importante a el servicio de Dios e de Su Magestad.

Y ansí mismo save que a los testigos que an llamado o a munchos dellos porque no decían lo que les preguntavan les decían que avía excomunión reservada a el Papa, y esto lo save por averlo oydo decir y que lo an dicho y publicado las personas a quien el dicho comisario y el escrivano de la comisión lo an dicho.

Y ansí mismo excede de la dicha comisión mandando a los cristianos biejos que están casados con moriscas que hagan ynformaciones de cómo son tales cristianos biejos, no obligándoles a ello el bando, y él por tener ocupación y quehacer lo hace. Y esto es la verdad y lo que save y a oydo decir por el juramento que tiene fecho. E lo firmó de su nonbre, y que es de treinta y seis años, poco más o menos. Dr. Basilio Alonso Suárez. Juan de Frías. Juan Rodríguez escrivano.

[3] En la Ciudad de Alcalá la Real, en el dicho día el dicho alcalde mayor para la dicha ynformación recivió juramento en forma de derecho de Alonso de Rojas presbitero, vezino desta Ciudad, so cargo del qual preguntado por la 
dicha caveça de ynformación, dixo que este testigo a sabido de Pedro de Oñate, fiscal de la comisión de Marcos Pérez de Prado, comisario que está en esta Ciudad sobre la expulsión de los moriscos, que el dicho comisario, escrivano, alguacil y fiscal tienen y llevan en cada un día los salarios contenidos en la caveça de ynformación, y no está cierto si le dixo si él tenía de salario trecientos o docientos maravedíes como tal fiscal.

Y para cobrar estos salarios a savido este testigo por cosa cierta an hecho repartimientos a cristianos biejos casados con cristianas nuevas, como son Pedro de Cicilia, Juan Ruiz Doncel y a un yerno suyo y a Alonso Gutiérrez y a otros que les an repartido a diez ducados y a dos ducados y un ducado, y todos los dichos repartimientos a oydo decir que los cobraba el alguacil de la dicha comisión, y porque el dicho Juan Ruiz no quería pagarlos por ser tal cristiano biejo, lo puso preso y estándolo los pagó.

Y save este testigo que cunplido el bando que hiço publicar, luego que vino a esta ciudad el dicho comisario hiso publicar otro por toda esta Ciudad con atanbores y el escrivano y fiscal y alguaciles a cavallo, por el qual mandó que todos los honbres, mugeres, muchachos y niños a quienes conprehendía el bando saliesen e se juntasen en el Espital y Corral de las Comedias para pasar lista y nombrar los comisarios y alguaciles que les que les [sic] llevasen a los puertos, con pena de la vida y perdimiento de bienes, obligando con esto a las cristianas nuevas que están casadas con cristianos biejos a que saliesen ellas y sus hijos, como salieron, y que pasasen lista en el patio de la Hermita de la Veracruz, que está junto con el Corral de las Comedias, aunque se avían registrado, cunpliendo con el primero bando; y a la dicha lista y junta concurrió y se juntó muncha jente, de lo qual resultó grande escándalo y murmuración de tan grande eceso, por estar como están ya registradas, y a las susodichas y a sus maridos y hijos desonra e ynfamia, porque algunas de ellas no era público eran moriscas, y de la dicha lista no a resultado expeler a ninguna persona, eceto a Melchor de Góngora mercader, que a éste lo quiso y mandó llevar a Motril y para esto le prendió y secrestó todos sus bienes, y otro día después de averlo llevado lo volvieron a esta Ciudad, y entonces vido este testigo el dicho alguacil y alcavuceros, y el mismo día oyó decir lo avían llevado a Granada.

Y el día que se secrestaron los vienes le dijo a este testigo Simón Pérez presbítero que avía puesto arcavuces de guarda en la casa e tienda del dicho Melchor de Góngora y que avían echado a la muger y hijos del dicho Melchor de Góngora de su casa, siendo cristiana bieja, y la avía cerrado con las llaves.

$\mathrm{Y}$ ansy mismo save que el dicho comisario procede contra testigos que an dicho en ynformaciones fechas por algunas personas y los tiene presos, esto sin aver convencido a la parte a cuyo pedimiento se hicieron las ynformaciones ni estar sus caussas sentenciadas ni fécholes cargo, sino con la sumaria ynformación que él a hecho. 
Y todo lo susodicho le parece a este testigo ecesso y cosas dignas de remedio, de lo qual resultará servicio de Dios, nuestro señor, y de Su Magestad, y esto le parece a este testigo que procede ser el dicho Marcos Pérez de Prado moço que sigún su aspecto le parece a este testigo tendrá veinte años, poco más o menos, y ser soldado y honbre de pocos negocios y exsperiencia, y esto es la verdad y lo que save por el juramento que tiene fecho. E lo firmó de su nonbre y que es de treinta y seis años, poco más o menos. Dr. Basilio Alonso Suárez. Alonso de Roxas. Juan Rodríguez escrivano.

[4] En el dicho día, mes y año, dicho señor el señor alcalde mayor recivió juramento según forma de derecho de don Juan del Castillo Hinojosa, vecino desta Ciudad, so cargo del qual siendo preguntado dijo que este testigo save y es notorio está en esta Ciudad Marcos Pérez de Prado, comisario juez subdelegado de don Francisco Yrarraçával y Andía, juez que está en la Ciudad de Granada entendiendo en la espulsión de los moriscos, y a visto este testigo cómo el dicho Marcos Pérez de Prado tiene su audiencia en esta Ciudad con alguacil, escrivano y fiscal, y a oydo decir que tiene el dicho juez de salario mill maravedíes y el alguacil seiscientos y el escrivano quinientos y el fiscal, que es un procurador desta Ciudad, trescientos maravedíes; y los susodichos an procedido y van procediendo contra personas de calidad y honradas, sin que se aya entendido que son moriscos, ni que este testigo aya oydo ni entendido cosa al contrario, antes tiniéndoles por gente honrada y principal, de buena opinión y reputación, sin raçón de aver procedido contra ellos; i a avido y ay en esta Ciudad muy grande nota y escándalo y murmuración, dando mano a maldicientes y personas malyntincionadas para que digan y murmuren de la gente honrada.

Y a visto este testigo cómo el dicho Marcos Pérez de Prado es moço de poca edad y de poca espirencia en negocios y que procede sin consejo y parecer de letrado, y assí haze grandes repartimientos a cristianos biejos qu'están casados con moriscas, como son Juan Ruiz Doncel, Pedro de Cicilio, que son cristianos biejos; y este testigo a visto sus papeles y son muy buenos y de consideración, y otros vecinos desta Ciudad, llevándoles a diez ducados más y menos, de manera que con evidencia se ve que an llevado muchos ducados, y quando no los pagan, luego yncontinente procede contra ellos con mucho rigor. Y assí sobre esto como sobre lo demás que le parece a este testigo que ecede de su comisión, según los bandos de Su Magestad, a avido y ay en esta Ciudad muy grande alboroto y escándalo y murmuraciones en raçón de proceder contra gente honrada, y que nunca se entendió tal, y esto es grande agravio que se haze en esta Ciudad, porque a este testigo le parece que no se hace más de para quitar honras y haciendas, porque contra la gente que procede es gente honrada y que nunca desde que este testigo se save acordar a oydo deçir contra sus linajes cosa mala ni que perjudique a sus honras, hasta que el dicho Marcos 
Pérez de Prado vino a esta Ciudad, que por ser moço y de poca edad y tener tan poco espirencia los autos que provee son comparecer de su escrivano, que es Diego de Velasco, que es público y notorio y cosa muy savida y entendida en esta Ciudad.

Y assí mismo, es público e notorio en ella que los testigos que van a deçir sus dichos el dicho fiscal y escrivano los atemoriçan diciendo que ay descomunión reserbada a la ausulución para el Papa, si no dicen lo que se les pregunta, y amenaçándoles con otras amenaças, de manera que escandaliçan a los testigos; y llamando a Luis de Narváez Luján para que se ratificase en un dicho que avía dicho en favor de Andrés de Mendoça y su muger, el dicho juez y escrivano no le querían mostrar su dicho, diciéndole que estava en Granada, y que hiciese preguntas y repreguntas para que se retratase en lo que tenía dicho, y el dicho Luis de Narváez pidió que se le leyese su dicho y profiando sobrello en efecto se lo binieron a mostrar y leer, y después de leydo y ratificado se le dijo a este testigo, el dicho Luis de Narváez, lo que le avía pasado y que si avía dicho algún dicho, que mirase cómo yba, que yban con ánimo y cautela de que se perjurasen, no mostrándoles sus dichos, tiniéndoles allí, finjiendo que estavan en Granada.

Y assí mismo save este testigo que el dicho juez procede contra biudas honradas que an sido casadas con cristianos viejos y tiene presos testigos de ynformaciones que se an hecho, antiguas, sin entrar ni salir en los bandos de $\mathrm{Su}$ Magestad; y a hecho secresto de bienes muebles y raíces y prisiones, de manera que ay en esta Ciudad los dichos escándalos y murmuraciones que tiene dichos.

Demás de que el dicho juez a visto este testigo que no a procedido contra moriscos berdaderamente respecto de ser pobres sin oficio, con Melchor de Góngora, que teniendo hechas sus provanças muy antiguas de hijo de cristiano viejo y aviéndose quedado en esta Ciudad por tal abrá veinte y siete o veinte e ocho años en la expulsión que estonçes se hiço, porque este testigo a visto las listas pocos días a y está en los rescatados el dicho Melchor de Góngora, diciendo quedóse por cristiano viejo, y de presente, sin enbargo de todos sus recaudos, sin oyrlo le secrestaron sus bienes y le prendieron con mucho alboroto, llebándolo con alcavuceros y alguacil y gente, sacándolo de la cárcel en medio del día, causando grande escándalo, en raçón de no oyr al dicho Melchor de Góngora, al qual decían lo llevaban a enbarcar, y save el dicho testigo que al dicho Melchor de Góngora lo bolvieron desde'l camino a esta Ciudad un día por la mañana y a la tarde lo bolvieron a sacar de la dicha cárcel con el dicho alboroto, y en la casa del dicho Melchor de Góngora a oydo decir este testigo públicamente que después con alcavuseros de guarda, echando a su muger, que es cristiana vieja, y a sus hijos en la calle, sin dejarles sacar para dormir ni comer este día, lo qual causó en esta Ciudad grandes lástimas a los que los avían e beyan. 
Y assí mismo save este testigo que el dicho Melchor de Góngora tenía sentencia de los auditores del Marqués de San Jermán en su favor, y Andrés de Mendoça y su muger assimismo, y pendientes sus causas ante el Conde de Salaçar, y [nombre borrado], assimismo vezino desta Ciudad, tenía sus papeles y recaudos del dicho Conde de Salaçar, en que no le comprehendía el bando, sin enbargo de todo ello, el dicho juez procedió contra todos ellos y los prendió y tiene algunos presos, haciéndoles molestias y bejaciones dignas de remedio, pues Su Magestad como tan católico no quiere ni permite que en sus Reinos se hagan con tantas desórdenes como este testigo a visto que se hacen en esta Ciudad.

Y assí mismo bido este testigo que el dicho juez echó bando luego que él vino a esta Ciudad por el que mandó que todos los moriscos y moriscas y sus hijos dentro del término contenido y conprehendido en el dicho bando se registrasen ante él, en cuyo cunplimiento a oydo decir este testigo que todos los moriscos y moriscas se registraron, y assimismo las moriscas que estavan casadas con cristianos biejos, y cumplido el dicho término hiço publicar otro bando por toda esta Ciudad con atanbores, escrivano, alguaciles y fiscal a cavallo, por el qual mandó que todos los dichos hombres, mugeres, niños y muchachos se juntasen en el Corral de las Comedias para nombrarles alguaciles y comisarios que los llevasen a los puertos; y en cumplimiento del dicho bando se juntaron y concurrieron en el dicho patio y corral mucha gente, entre los quales iban mugeres de cristianos biejos, de lo qual les resultó desonra e ynfamia, porque al tiempo de pasar la dicha lista avía y uvo mucha gente que avían salido a ver la dicha lista. Y ésta es la verdad so cargo del dicho juramento, y lo firmó, que es de hedad de más de treinta y tres años. Dr. Basilio Alonso Suárez. Don Juan de Hinojosa. Juan Rodríguez escrivano.

[5] En el dicho día, mes y año dichos, el dicho alcalde mayor recivió juramento en forma de derecho de don Fernando Cabrera y Aranda, vecino desta Ciudad, so cargo del qual, siendo preguntado dijo que lo que save es que avrá veinte días, poco más o menos, que está en esta Ciudad un comisario para la espulsión de los moriscos, que se llama Marcos Pérez de Prado, el qual está por horden de don Francisco de Yraraçával y Andía que se dice que reside en la dicha comisión en la Ciudad de Granada; y a visto este testigo que el dicho Marcos Pérez de Prado hace muchos autos por ante Diego de Velasco e con el fiscal que procura de antes, y públicamente se an quejado y se quejan muchos vezinos desta Ciudad, assí cristianos biejos derechamente casados con moriscas y otros que tienen pleitos pendientes en el Consejo del Rei, nuestro señor, y su Estado, y otros que de nuevo pretende aberiguar ser cristianos biejos por ser hijos de cristianos biejos paternos, e que el dicho comisario, escrivano y fiscal les hacen grandes desafueros, como son llevándoles repartimientos de dinero a los cristianos biejos derechamente y a los que pretenden serlo tan ygual- 
mente, como si derechamente fuesen moriscos de toda su nación, siendo como es contra los bandos de Su Magestad, porque por ellos es claro no comprehendelles a las moriscas que están casadas con cristianos biejos; demás que en la presentación de las peticiones que an presentado los dichos cristianos biejos alegando sus ecepciones y pidiendo su justicia conforme a los dichos bandos, se quejan públicamente que por cada petición les llevan doce reales.

Demás que el día que se alistaron les mandó juntar el dicho comisario en un patio de las Comedias, que es en la Veracruz, adonde hiço parecer a los dichos cristianos biejos juntamente con sus mugeres por ser moriscas, en lo qual a los de todo este lugar y república pareció grande agravio que se les hacía a los dichos cristianos biejos y oprovio.

Y save este testigo por cosa cierta y berdadera que procediendo el dicho comisario y el escrivano contra personas muy honradas y en puesto muy honroso y que lo estuvieron todos sus pasados tiniendo oficios públicos y reales y contando por provanças muy ebidentes y causa fulminada en virtud de cédula real de Rey, nuestro señor, de gloriosa memoria, Phelipe Segundo, que el dicho comisario y los demás sus oficiales por derocallos desta posesión y estado honroso les an caluniado al contrario de la verdad, diciendo ser moriscos, haciendo en minuta lo que a su propósito avían de escrivir, aunque los testigos dijesen otra cosa, y parece ser esto verdad, por raçón que aviendo llamado a un Pedro López de la Caveça, vezino de la villa del Castillo, sobre el mismo caso, escrivieron lo que estava en la minuta referida, y leyéndole el dicho al dicho Pedro López de la Caveza, dijo que no avía dicho aquéllo y que lo que decía era diferente de aquello, y el dicho escrivano rompió y hiço dos partes el dicho dicho, que la una parte de él sacó a la plaça de la dicha villa, y se bolvió a escrivir otra cosa de lo que estava escripto, y desto dijo el dicho Pedro López públicamente que estava receloso si se avía escripto la verdad o no. Y todo lo referido este testigo se lo oyó decir a don Rodrigo de Mendoça, regidor desta Ciudad, y a Cristóval Muñoz, assimismo regidor, y a Juan de Sacedo, escrivano público, y assí mismo les oyó decir que se quejavan y estava con el mismo recelo Pedro Ruiz de Molina, suegro de Alonso Jordán, que le subcedió el mismo caso con los susodichos, y tanbién que aviéndole mandado benir a esta Ciudad a Juan Ruiz de la Rosa para que dijese su dicho contra esta gente honrada que está referida, dijo que lo que savía era que avía treinta años que residía en la dicha villa y que conocía a las personas que le preguntavan y las avía tratado y comunicado, y que él y sus mayores y gente muy honrada los avían aquellos por quien preguntavan por cristianos biejos y de buena bida y fama, y que él los avía tenido por tales sin aver oydo cosa al contrario, y aviéndole oydo, el dicho escrivano y comisario lo que decía le dixeron que se fuese con el diablo, que quien lo avía llevado, y que estava con recelo si se avía escripto lo que avía dicho u otra cosa.

Por todo lo qual, a este testigo le parece demás de avello oydo decir y comunicar con personas de ciencia y conciencia, que el proceder del dicho comi- 
sario y escrivano antes hera ynfamar honras de gentes honradas que cumplir los bandos de Su Magestad, buscando causas y excesos para detenerse en esta Ciudad, escriviendo respecto de no tener comisión limitada, y por llevar muchos salarios, según los repartimientos que ha hecho para llevar los salarios que en el auto de la justicia desta Ciudad se face minción.

Y además desto save este testigo y es cosa pública y notoria que dicho comisario y escrivano, contrabiniendo los dichos bandos y dándoles diferente sentido a su propósito, con deferentes jentes que moriscos, hacen muy grandes desafueros para usar y goçar de los dichos salarios. Y esto es la verdad so cargo del juramento.

Demás de lo qual save por cosa berdadera este testigo que aviendo traydo a esta Ciudad un proceso original de la de Granada para que el dicho comisario y escrivano ratificasen los testigos que avían dicho en la causa en favor de Andrés de Mendoça e Ysavel de Padilla, su muger, por ser hija de cristiano biejo, llegando a la muger y hija de Luis de Narváez Luján, gente principal y honrada, a que dijesen sus dichos segunda bez, pidieron que les leyesen sus dichos que avían dicho, y no lo quisieron hacer y desto se quejava en la plaça desta Ciudad el dicho Luis de Narváez públicamente.

Y assimismo, este testigo a oydo decir que el dicho don Francisco Yraraçával y Andía con la relación que el dicho Marcos Pérez de Prado y el dicho Diego de Velasco le avían hecho, avía proveydo auto contra Melchor de Góngora y que era sin parecer del acesor, sino de su propia autoridad, en que le manda espeler y ponello en execución sin oyllo ni dalle traslado, que a toda esta Ciudad tiene escandaliçada ber que en materia de justicia se determine la causa sin defensa, estando en opinión y por sentencia de cristiano biejo. Y esto es lo que dice debajo del dicho juramento, y lo firmó de su nombre, y que es de hedad de çinquenta y dos años, poco más o menos. Dr. Basilio Alonso Suárez. Fernando Cabrera y Aranda. Juan Rodríguez escrivano.

[6] En la Ciudad de Alcalá la Real, en el dicho día el dicho alcalde mayor para la dicha ynformación recibió juramento en forma de derecho de don Rodrigo de Mendoça, regidor y vezino desta Ciudad, so cargo del qual, preguntado por dicho auto y caveza de ynformación, dixo que este testigo save e tiene muy entera noticia de que está en esta Ciudad Marcos Pérez de Prado, comisario subdelegado de don Francisco de Yrarraçával, juez que está en la Ciudad de Granada sobre la espulsión de los moriscos, el qual tiene su audiencia en esta Ciudad, y en ella escrivano, fiscal y alguacil, y a oydo decir que tienen los salarios que constan en el auto y caveza de ynformación y que no tiene comisión limitada. Y save que luego que vino a esta Ciudad el dicho comisario hizo publicar el bando de Su Magestad para que todos los moriscos y moriscas y sus hijos se registrasen dentro del término contenido en el dicho bando, en cuplimiento del qual a entendido este testigo por cosa cierta se registraron todas las perso- 
nas a quienes conprehendía y las moriscas que eran casadas con cristianos biejos, mandándoles se registrasen con peticiones, llevándoles los dichos oficiales ocho reales por los autos que se hacían con cada una petición, y algunos moriscos de los que los pagaron se lo an dicho a este testigo.

Y demás desto les a pedido a los dichos cristianos biejos que están casados con moriscas diesen ynformación de cómo eran y son cristianos biejos, todo a fin de tener qué hacer y escrivir por llevar salarios.

Y aviendo ydo a la villa del Castillo a hacer el dicho registro por ser lugar de la juridición de esta Ciudad, lo hicieron con tanto rigor y fieros que algunos cristianos biejos que tenían duda a sus mugeres, les tocava por agüelo o bisagüelo cosa tan poca que no se savía noticia dello, en la villa quisieron registrar sus hijos por las grandes penas que ponían de muerte y perdimiento de bienes y con el rigor con que decían lo avían de executar; y algunos cavalleros y otra jente de la dicha villa se lo estorbaron diciendo esa disparate.

Y procuraron hacer y hicieron ynformaciones sumarias a otras personas muy honradas desta Ciudad y a sus padres y abuelos, an estado en buena reputación y aviendo en el dicho linaje frayles y clérigos y monjas, por ser su descendencia de la dicha villa exsaminaron munchos testigos, procurando quitarles la honra diciendo son moriscos y prendiendo a uno dellos, dando causa a que con ellos y con otras personas honrradas sus enemigos y jente apasionada tomen venganza de sus pasiones, y aún mostrándose ellos tanvién apasionados en el examen de los testigos, procurando que dijesen lo que ellos querían, llevando minutas de lo que avían de decir, y aviendo dicho su dicho Pedro Ruiz de Mula, vezino de la dicha villa, le dijeron el dicho comisario y el escrivano cómo no decís de fulano que bibe en la dicha villa, declarándole de nombre, diciéndole hijos e nietos de quien era, y el susodicho dixo si vuestra merced lo traya escrito pónganlo para quienes lo preguntan; y a Pedro López de la Caveza, que fue otro testigo, a oydo decir este testigo a persona a quien el dicho Pedro López se lo dijo, que aviendo dicho su dicho, pidió que se lo leyesen, y aviéndoselo leydo el escrivano, dijo que él no avía dicho lo que estava escrito, y ansy lo ronpieron y se bolvió a escrivir, el qual y otros testigos que exsaminaron a oydo decir que se an quejado que les apretaron mucho en sus dichos, preguntándoles y pretendiendo dijesen cosas que ellos ni sus padres no lo podían saver por aver más de ciento y treinta años que avía pasado lo que se les preguntava.

Todo lo qual tiene este testigo por muy grande exceso y le pareze que sólo sirve de hacer papeleras y ocupaciones para llevar salarios y quitar honras a mucha jente honrada y a cristianos biejos que están casados con cristianas nuevas, haciéndoles salir a registro público, que a oydo decir este testigo se hiço en el Corral de las Comedias y patio de la yglesia de la Santa Veracruz desta Ciudad, donde avía concurrido muncha jente a ver el dicho registro público, todo lo qual es cosa digna de remedio y dello se servirá Dios, nuestro señor, y mu- 
chas personas, que se escusarán munchas ofensas de Dios y murmuraciones y escándalos que ay en esta Ciudad del proceder y excesos del dicho comisario y sus oficiales, y que esto él save so cargo del dicho juramento, y lo firmó de su nombre, y declaró ser de edad de veinte e cinco años, poco más o menos. Dr. Basilio Alonso Suárez. Don Rodrigo de Mendoça i Salazar. Juan Rodríguez escrivano.

[7] En la dicha Ciudad de Alcalá la Real, en dicho día el dicho alcalde mayor para la dicha ynformación recivió juramento en forma de derecho de Miguel de Utrilla, regidor desta Ciudad y vezino della, so cargo del qual preguntado por el dicho auto y caveza de la ynformación, dijo que save y es público e notorio en esta Ciudad [que] está en ella Marcos Pérez de Prado, juez comisario subdelegado de don Francisco de Yrarraçával y Andía, comisario que está en la Ciudad de Granada sobre la espulsión de los moriscos, con su audiencia, como se dice en el dicho auto, y que todos los oficiales tienen los salarios que en él se dizen porque así lo a oydo decir a ellos propios este testigo.

Y save que luego que vino a esta Ciudad començaron a usar y hacer su comisión, haciendo publicar bandos con grandes penas, y que luego a cabo de pocos días save este testigo prendieron a Francisco de Herrera Balenzuela, regidor y depositario general desta Ciudad, por decir avía favorecido a Andrés de Mendoza y su muger, y se echó fama en esta Ciudad que con su favor estavan en ella, siendo diferentes, porque los susodichos tenían setencia y recaudos bastantes de los alcaldes de la Ciudad de Syvilla, auditores y acesores del Marqués de San Jermán, a quien primero se cometió la dicha espulsión, teniendo mandamiento del Conde de Salazar y del alcalde Gregorio López Madera para llevar sus procesos y causas originales a el Consejo para ser oydos de su justicia; y luego que llegó los prendió a marido y muger y con ellos a otros y de Granada binieron por mandado del dicho don Francisco, quatro alguaciles y un escrivano y quatro alcabuceros que cojiesen en esta Ciudad, y a todos juntamente con el dicho Francisco de Herrera, los llevaron presos, ofreciendo el dicho Francisco de Herrera munchas fianças de siguridad para haser el [...] y presentarse y para lo llevar el dicho Marcos Pérez le sacó quatrocientos reales para pagar los dichos alguaciles, guardas y cavalgaduras; y luego que salió desta Ciudad, el dicho comisario fue a casa del dicho Francisco de Herrera y le secrestó sus bienes y hiço depósito dellos en este testigo; y save que lo a tenido preso en la Ciudad de Granada con dos alguaciles de guarda, estando sin culpa, como constará de los autos y proceso a que se remite.

$\mathrm{Y}$ ansy mismo save que se an enbargado al dicho Francisco de Herrera todos los corridos de los censsos que tiene en esta Ciudad y su villa del Castillo y otras partes, causándole en ello munchas costas, y le a librado dos mandamientos para que dé veinte y tres ducados y tres reales a este testigo como de- 
positario de los dichos bienes y todo de costas y gastos para molestar al dicho Francisco de Herrera.

Y save este testigo que el dicho comisario procedió contra Melchor de Góngora por decir conprehenderle el bando y le secrestó los bienes y hiço depositario dellos a este testigo y le mandó dar quatrocientos y ochenta y seis reales y medio para pagar las costas que le pertenecían.

$\mathrm{Y}$ ansy mismo a oydo decir que a fecho repartimientos de salarios a cristianos biejos casados con moriscos, como son a Juan Ruiz Doncel y a su yerno y a Pedro de Cecilio mercaderes y a otras personas, todo lo qual le parece a este testigo que son excesos y agravios que los dichos juezes y comisarios an hecho y hacen, los quales son dignos de remedio, porque se procede contra muchas gentes onradas que están en opinión de cristianos biejos, de que ay escándalo en esta Ciudad y muncha nota y será servicio de Dios remediar los dichos excesos, y con que Su Magestad será servido. Y esto es la verdad so cargo del dicho juramento, y lo firmó de su nombre, y que es de çinquenta años, antes más que menos. Dr. Basilio Alonso Suárez. Miguel de Utrilla. Juan Rodríguez escrivano.

Entregué un traslado desta información este día a el señor alcalde mayor autoriçado.

1611, julio 19-24. Alcalá la Real

Resumen del resto de los Autos

- Diligencia de entrega de traslado autorizado de las anteriores deposiciones.

- Petición de don Diego Cabrera y Pedro de Barrionuevo Aragonés, comisarios designados por el municipio contra la actuación del Alférez Marcos Pérez, al alcalde mayor para que les dé traslado de la información relacionada anteriormente. Contestación positiva (19 de julio) y recibo del mismo ( 20 de julio).

- Auto del alcalde mayor sobre las noticias que acababan de llegarle, sobre que el comisario Pérez, enterado de la información efectuada de sus excesos, había dado orden de sacar a todos los que tenían presos en la cárcel pública de Alcalá, para llevarlos de inmediato a Granada.

- Deposiciones de testigos:

- Deposición de Pedro de Havastro, teniente de alcaide de la cárcel de Alcalá sobre esos hechos (1).

- Deposición de Francisco Fernández de Anguita, vecino de Alcalá, sobre tales extremos (2).

- Deposición de Pedro Muñoz, preso en la cárcel pública, sobre lo mismo (3). 
- Auto del alcalde mayor requiriendo a Diego de Velasco, escribano público de Alcalá y de la comisión de Marcos Pérez, entrega de un testimonio sobre los bienes secuestrados por el comisario Pérez, los repartimientos hechos, las personas presas y los motivos de su prisión (19 de julio).

- Contestación del escribano, alegando la imposibilidad de cumplir tal requerimiento, ya que toda la documentación la guardaba el comisario en su poder.

- El alcalde mayor ordena poner preso al dicho escribano.

- Alegación del escribano Velasco, aduciendo que el testimonio que se le había requerido se lo había arrebatado el comisario tras haberlo sacado.

- Auto del alcalde mayor solicitando traslado de todo lo anotado para comunicarlo al Rey (19 de julio).

- Auto del alcalde mayor requiriendo de núevo al escribano Velasco entregue el testimonio que se le había ordenado (20 de julio).

- Contestación del escribano de la imposibilidad de proceder a ello a causa de la oposición del comisario; que apremie a éste directamente.

- Auto del alcalde mayor requiriendo al comisario Pérez haga entrega del testimonio sobre sus anteriores actuaciones ( 21 de julio).

- Auto del alcalde mayor ordenando a los depositarios de los bienes confiscados por el comisario Pérez que no libren cantidad alguna al dicho comisario para su salario y el de sus oficiales, en tanto se determina si dichos salarios son justos y se confiscan oficialmente dichos bienes.

- Notificación del auto al regidor Miguel de Utrilla, depositario de los bienes de Francisco de Herrera Valenzuela, regidor y depositario general de la Ciudad.

- Notificación del auto al regidor Pedro de Barrinuevo Aragoneses, depositario de los bienes de Juana de León, viuda de Miguel de Castro, en unión de Pedro Vázquez Messía y Juan de Ortega.

- Auto del alcalde mayor para averiguar los salarios y repartimientos cobrados por el comisario Pérez de Prado:

- Deposición de Pedro de Cecilio mercader, vecino de Alcalá, sobre la cantidad que el comisario le había repartido a él y a otros vecinos: imputaba a su mujer, Catalina Hernández, el ser morisca, cuando sólo lo había sido su madre, mas no su padre.

- Requerimiento, notificación, exhibición e inclusión del original de la carta de pago entregada a Pedro de Cecilio.

- Deposición de Juan Ruiz Doncel mercader, vecino de Alcalá, sobre lo mismo: le imputaban el que su mujer, Bernardina Sánchez, fuera morisca.

- Requerimiento, notificación, exhibición e inclusión del original de la carta de pago entregada a Juan Ruiz Doncel.

- Deposición de Diego de Contreras sastre, vecino de Alcalá, sobre lo mismo. 
- Requerimiento, notificación y exhibición de la carta de pago entregada a Diego de Contreras.

- Deposición de Juan Hernández, antiguo cocinero del Abad, cuya mujer era morisca, sobre lo mismo.

- Requerimiento, notificación y exhibición de la carta de pago.

- Deposición de la morisca Isabel de Zafra, mujer de Pedro Hernández de Castilla, cristiano viejo, vecina de Alcalá, sobre lo mismo.

- Deposición de Catalina Hernández, viuda de Juan Alonso, vecina de Alcalá, sobre lo mismo.

- Deposición de la morisca Isabel Ruiz, viuda de Rodrigo Alonso de Almodóvar, cristiano viejo, vecina de Alcalá, sobre lo mismo.

- Deposición de la morisca Luisa de Góngora aceitera, mujer de Martín Ruiz Suárez, cristiano viejo, vecina de Alcalá, sobre lo mismo.

- Deposición de Juan Ruiz Chabarrías, vizcaíno, cristiano viejo, esposo de la morisca María Sánchez de la Tienda, vecinos de Alcalá, sobre lo mismo.

- Deposición de Miguel García casero, vecino de Alcalá, sobre lo mismo.

- Requerimiento, notificación, exhibición e inclusión del original de carta de pago entregada a Miguel Martín casero.

- Deposición de Gaspar Hernández, portugués residente y vecino de Alcalá, sobre lo mismo; su esposa era hija de cristiano nuevo y morisca. mismo.

- Deposición de Miguel Sánchez de Iváñez, vecino de Alcalá, sobre lo

- Deposición de Baltasar Ruiz, vecino de Alcalá, sobre lo mismo.

- Auto del alcalde mayor ordenando incluir el documento de la comisión de Marcos Pérez en lo procesado, que el interesado acababa de remitirle en cumplimiento de requerimiento anterior ( 22 de julio). Falta el traslado.

- Deposición de Diego de Velasco, escribano público y de la comisión de Marcos Pérez, vecino de Alcalá, sobre lo anterior.

- Deposición de Pedro de Gamboa sastre, hermano del Licenciado Francisco de Gamboa, vecinos de Alcalá, sobre lo mismo (24 de julio).

\section{RELACIÓN DE PERSONAS CITADAS EN EL PROCESO}

Alarcón, Juan de (jurado).

Alonso, Juan; difunto; cristiano viejo casado con la morisca Catalina Hernández.

Alonso de Almodóvar, Rodrigo; difunto; cristiano viejo casado con la morisca Isabel Ruiz.

Alonso Suárez, Doctor Basilio (alcalde mayor de la Ciudad).

Argüello, don Gutierre de.

Avastro, Licenciado (...). 
Avastro, Juan de (alcaide de la cárcel pública de la Ciudad).

Avastro, Pedro de (teniente de alcaide de la cárcel) (18 años).

Barrionuevo Aragonés, Pedro de (regidor y diputado contra el comisario).

Bastián (...), vecino de la Calle de la Mesa, cristiano viejo casado con morisca.

Cabrera, don Diego (regidor y diputado contra el comisario).

Cabrera y Aranda, don Fernando (52 años).

Campo, Baltasar del (alhondiguero).

Castillo Hinojoso, don Juan del (33 años).

Castro, Miguel de; difunto; cristiano viejo casado con la morisca doña Juana de León.

Cecilio, Pedro (mercader); cristiano viejo casado con la morisca Catalina Hernández (32 años).

Contreras, Diego de; cristiano viejo casado con morisca.

Contreras, Pedro de (sastre); hermano de Diego (28 años).

Falcon, María de; morisca, casada con el cristiano viejo Alonso Hernández.

Flores, Juan de (labrador); cristiano viejo casado con morisca.

Frías Vázquez, Juan de (presbítero) (36 años).

Gamboa, Francisco de (licenciado, letrado de la Ciudad), procesado por encubrir a moriscos.

Gamboa, Pedro de (sastre, hermano del licenciado).

García, Miguel (casero); cristiano viejo casado con morisca (50 años). Ecija.

Garrida (...); morisca, casada con el cristiano viejo Juan Martínez de

Góngora, Luis de (aceitera), morisca, casada con el cristiano viejo Martín Ruiz Suárez.

Góngora, Melchor de (mercader); dudoso cristiano viejo, expelido a Motril y devuelto, casado con cristiana vieja.

González de Castilla, Pedro.

Gutiérrez, Isabel; morisca, viuda de cristiano viejo, vecina de la calle de la Peste.

Hernández, Alonso; cristiano viejo casado con la morisca María de Falcón.

Hernández, Catalina; hija de morisca, casada con el cristiano viejo Pedro de Cecilio.

Hernández, Catalina; morisca, viuda del cristiano viejo Juan Alonso (68 años).

Hernández, Juan (ex cocinero del Abad); cristiano viejo casado con morisca (49 años).

Hernández de Anguita, Francisco (40 años).

Hernández de Castilla, Pedro; cristiano viejo casado con la morisca Isabel de Zafra. 
Hernández Portugués, Gaspar; cristiano viejo casado con la morisca Juana de la Tienda (40) años.

Hernández de Vioso, Alonso; cristiano viejo casado con morisca.

Herrera y Valenzuela, Francisco de (regidor y depositario general de la Ciudad), procesado por encubrir moriscos.

Iváñez, Martín (hermano de Miguel Sánchez de Iváñez); cristiano viejo casado con morisca.

Jiménez, Pedro (procurador).

Jordán, Alonso; vecino del Castillo de Locubín.

León, doña Juana de (o de La O); morisca, viuda de Miguel de Castro.

López de la Cabeza, Pedro; vecino del Castillo de Locubín.

Martínez de Ecija, Juan; cristiano viejo casado con Garrida, la morisca.

Mendoza, Andrés de; cristiano viejo casado con la morisca Isabel de Padilla.

Mendoza, don Rodrigo de (regidor) (25 años).

Montilla, Bernabé de; cristiano viejo casado con morisca.

El suegro de Bernabé de Montilla; cristiano viejo casado con morisca.

Muñoz, Cristóbal (regidor).

Muñoz, Lorenzo; cristiano viejo casado con morisca, vecino de la calle de Juan Martínez de Ecija.

Muñoz, Pedro (preso en la cárcel) (18 años).

Narváez Luján, Luis de.

Oñate, Pedro de (procurador y fiscal de la comisión).

Ortega, Juan de.

Padilla, Isabel de; morisca, hija de cristiano viejo y morisca, casada con el cristiano viejo Andrés de Mendoza.

Pérez, Simón (presbítero).

Raya, Salvador de; yerno de Juan Ruiz Doncel, cristiano viejo casado con morisca.

Rodríguez, Juan (escribano público).

Rojas, Alonso de (presbítero) (36 años).

Rojas, Diego de; expelido para ser embarcado en Málaga, fue devuelto.

Rotarta, Juan de (o Retarta).

Ruiz, Baltasar; cristiano viejo casado con hija de morisca (23 años).

Ruiz, Isabel; morisca, viuda del cristiano viejo Rodrigo Alonso de Almodóvar (más de 50 años).

Ruiz Chabarrías, Juan, vizcaíno, cristiano viejo casado con la morisca Juana de la Tienda (más de 60 años).

Ruiz Doncel, Juan (mercader); cristiano viejo casado con la morisca Bernardina Sánchez.

Ruiz de Molina, Pedro; vecino del Castillo de Locubín.

Ruiz de la Rosa, Juan; vecino del Castillo de Locubín. 
Ruiz Suárez, Martín; cristiano viejo casado con la morisca Luisa de Góngora.

Sacedo, Juan de (escribano público).

Sánchez, Bernardina; morisca casada con el cristiano viejo Juan Ruiz Doncel.

Sánchez, Sebastián; cristiano viejo casado con morisca.

Sánchez de Iváñez, Miguel; cristiano viejo casado con morisca (30 años).

Sánchez de la Tienda, María; morisca casada con el cristiano viejo Juan Ruiz Chabarrías.

Tienda, Juana de la; morisca casada con el cristiano viejo Gaspar Hernández Portugués.

La madre de Juana y María Sánchez de la Tienda; morisca.

Tordesillas, Hernando de.

Utrilla, Miguel de (región) (50 años).

Vázquez Mesía, Pedro (regidor) (más de 30 años).

Velasco, Diego de (escribano público y de la comisión) (44 años).

Zafra, Isabel de; morisca casada con el cristiano viejo Pedro Hernández de Castilla (40 años).

\title{
RESUMEN
}

La expatriación de los moriscos españoles fue un proceso en el que se pusieron a prueba los medios administrativos de la Corona y, muy especialmente, la tenaz resistencia de los implicados, que por todos los medios intentaron evitarla; sólo en 1611 puede decirse que el extrañamiento se había completado de forma aceptable para los responsables. En el presente estudio se pasa revista a las actividades desarrolladas en esa última hora en Alcalá la Real por parte del Alférez Marcos Pérez de Prado, comisario delegado de Francisco de Irrazábal y Andía, encargado de la expulsión en el Reino de Granada. La radical actuación del alférez en el desempeño de su contenido tuvo la virtud de levantar el clamor de las fuerzas vivas de la localidad, lo que nos ha permitido conocer, no sólo los pormenores del acontecimiento, sino, sobre todo, la permeabilidad social y étnica, además de la tolerancia no siempre desinteresada existente en este rincón gienense.

\begin{abstract}
The expulsion of the Moriscos was a process in which both the administrative resources of the monarchy and, especially, the staunch resistance of those affected (who tried to avoid it by all possible means) were put to the test. Those responsible for implementing the expulsion assumed that their task had been
\end{abstract}


completely accomplished in 1611 . This article describes the activity of the second lieutenant (alférez) Marcos Pérez Prado in Alcalá la Real during that year. Pérez Prado was the deputy officer of Francisco de Irrazábal y Andía, assigned to supervise the expulsion of Moriscos in the Kingdom of Granada. Pérez Prado's resolute actions and his zeal to fulfil his duties provoked clamorous protests among the inhabitants of Alcalá la Real. This article provides us with a detailed account of the event, of the social and ethnic permeability prevalent at the time and the not always unselfish tolerance of the people living in that particular spot of the province of Jaén. 